\title{
The roles of mitoferrin- 2 in the process of arsenic trioxide-induced cell damage in human gliomas
}

\author{
Chunlei Wang ${ }^{\dagger}$, Xiaofeng Chen ${ }^{\dagger}$, Huichao Zou, Xin Chen, Yaohua Liu and Shiguang Zhao
}

\begin{abstract}
Background: Among glioma treatment strategies, arsenic trioxide $\left(\mathrm{As}_{2} \mathrm{O}_{3}\right)$ has shown efficacy as a therapeutic agent against human gliomas. However, the exact antitumor mechanism of action of $\mathrm{As}_{2} \mathrm{O}_{3}$ is still unclear. Mitochondria are considered to be the major source of intracellular reactive oxygen species (ROS), which are known to be associated with $\mathrm{As}_{2} \mathrm{O}_{3}$-induced cell damage. Therefore, we investigated whether mitoferrin-2, a mitochondrial iron uptake transporter, participates in $\mathrm{As}_{2} \mathrm{O}_{3}$-induced cell killing in human gliomas.
\end{abstract}

Methods: Human glioma cell lines were used to explore the mechanism of $\mathrm{As}_{2} \mathrm{O}_{3}$ 's antitumor effects. First, expression of mitoferrin-2 was analyzed in glioma cells that were pretreated with $\mathrm{As}_{2} \mathrm{O}_{3}$. Changes in $\mathrm{ROS}$ production and apoptosis were assessed. Furthermore, cell viability was assessed by 3-(4,5-dimethylthiazol-2-yl)-2,5-diphenyltetrazolium bromide (MTT).

Results: In the present study we found that $\mathrm{As}_{2} \mathrm{O}_{3}$ induced $\mathrm{ROS}$ production and apoptosis in glioma cells. In addition, gene expression of mitoferrin-2, a mitochondrial iron uptake transporter, was increased 4 to 5 fold after exposure to $\mathrm{As}_{2} \mathrm{O}_{3}(5 \mu \mathrm{M})$ for 48 hours. Furthermore, apoptosis and cytotoxicity induced by $\mathrm{As}_{2} \mathrm{O}_{3}$ in glioma cells were decreased after silencing the mitoferrin-2 gene.

Conclusions: Our findings indicated that mitoferrin-2 participates in mitochondrial ROS-dependent mechanisms underlying $\mathrm{As}_{2} \mathrm{O}_{3}$-mediated damage in glioma cells.

Keywords: Glioma, Mitoferrin-2, Apoptosis, Oxidative stress, Arsenic trioxide

\section{Background}

Glioma is a serious life-threatening disease, having the characteristics of invasiveness and a dismal prognosis. Chemotherapy and/or radiotherapy are the main approaches for glioma treatment after surgery. $\mathrm{As}_{2} \mathrm{O}_{3}$ as an antitumor agent has shown efficacy in treating glioma in laboratory tests $[1,2]$. Additionally, $\mathrm{As}_{2} \mathrm{O}_{3}$ has potential as a mitochondrial toxin that can induce reactive oxygen species (ROS) production; these mainly originate in the intracellular mitochondrial respiratory chain and further toxic byproducts subsequently produced could lead to mitochondrial damage [3]. In addition, excessive ROS production acts as key mediator of the apoptotic-signaling pathway. However, the detailed mechanism of $\mathrm{As}_{2} \mathrm{O}_{3}$-induced excessive ROS production remains unclear.

\footnotetext{
* Correspondence: guangsz@hotmail.com

${ }^{\dagger}$ Equal contributors

Department of Neurosurgery, The First Affiliated Hospital of Harbin Medical University, Harbin, People's Republic of China
}

Among numerous possible factors, such as altering the activity of enzymes, kinases, phosphatases and transcription factors [4], iron has been demonstrated in previous studies [5-9] to play an important role during ROS production in the mitochondrion. Because of the character of its redox properties, iron can catalyze the production of ROS, which are highly toxic [10], and increase the redox reaction [11].

Two main forms of iron exist in the cell: non-chelatable iron and chelatable iron. Lysosomes store amounts of chelatable iron [12], which promotes oxidative stress by catalyzing the Fenton reaction and produces highly reactive hydroxyl radicals. Excessive reactive hydroxyl radicals could damage DNA, proteins, and membranes. The concentration of cytosolic chelatable iron is low under normal conditions, but, in pathological conditions, chelatable iron released from lysosomes can increase cytosolic iron concentration [12]. Additionally, thelysosome-damaging ability of arsenite has been demonstrated [13] and it is also 
known that excessive mitochondrial ROS production requires more iron to cross the mitochondrial membrane. Therefore, we hypothesized that the mitochondrial iron transporter may participate in $\mathrm{As}_{2} \mathrm{O}_{3}$-induced excessive ROS production.

Mitochondria are considered to be the major source of intracellular ROS, which are knowingly associated with retrograde signaling and affect many cellular functions [14-16]. Mitoferrin, a mitochondrial protein, has been reported to mediate ferrous iron transport across the mitochondrial inner membrane $[11,17,18]$. Mitoferrin has two isoforms: mitoferrin-1 and mitoferrin-2, which are localized on the inner mitochondrial membrane and function as a requisite importer of iron for mitochondrial heme and iron-sulfur cluster (ISC) in erythroblasts [11]. Mitoferrin-1 is mainly distributed in erythroid cells with low levels in other tissues, whereas mitoferrin-2 is ubiquitously distributed [19]. In non-erythroid cells, mitoferrin-2 possibly functions to maintain the levels of cellular mitochondrial iron $[11,19]$. Previous research has reported that mitoferrin-2 transmits ferrous iron from cytoplasm to mitochondria. Additionally high mitoferrin2-expressing cells showed higher rates of mitochondrial ferrous iron uptake compared with low mitoferrin-2expressing cells [20]. Therefore, the possibility that the mitoferrin-2 transporter participates in $\mathrm{As}_{2} \mathrm{O}_{3}$-induced apoptosis in glioma should be considered.

In this study, our aim is to investigate whether mitoferrin-2 participates in the cytotoxic effect of $\mathrm{As}_{2} \mathrm{O}_{3}$ in human glioma and mediates the production of ROS.

\section{Methods}

\section{Source of reagents}

$\mathrm{As}_{2} \mathrm{O}_{3}$ compound was obtained from the Department of Pharmacy, the First Affiliated Hospital of Harbin Medical University (Harbin, China), and fresh dilutions with DMEM were used in each experiment. Mitoferrin-2 siRNA was designed and purchased from GenePharma (Shanghai, China). Annexin V-FITC-PI apoptosis detection kit (Baosea Biotechnology Co., Beijing, China) was used for detection of apoptosis by flow cytometry. For detection of ROS activity, 2',7' -dichlorofluorescin diacetate (Sigma-Aldrich, St. Louis, MO, USA) was used. Reverse transcriptase RT kit and real time PCR kit (Takara Biotechnology Co., Shiga, Japan) were used for the semiquantitation of mitoferrin-2 mRNA levels. Dimethylsulfoxide (DMSO) and 3-(4,5-dimethylthiazol-2-yl)-2,5-diphenyltetrazolium bromide (MTT) (Sigma-Aldrich, St. Louis, MO, USA) were used for detection of cell viability.

\section{Cell culture}

Human glioma cell lines, U87MG and T98G were cultured in DMEM(Hyclone, Logan, UT, USA) supplemented with $10 \% \mathrm{FBS}\left(\right.$ Hyclone, Logan, UT, USA) at $37^{\circ} \mathrm{C}$ in a humidified $\mathrm{CO}_{2}$ incubator, and $1 \%$ penicillin-streptomycin. The cells were passaged twice weekly, and once they were nearly confluent, they were released with $0.25 \%$ trypsinethylenediaminetetraacetic acid (EDTA) [21].

\section{RNA interference studies}

The siRNA specific sequences of human mitoferrin-2 transporter were designed according to standard procedures, and obtained from Shanghai GenePharma (Shanghai, China). The sequences were:

5'-GGCAACAUUACUUCAUGAUTT-3' and 5' -AUC AUGAAGUAAUGUUGCCTT-3'; and the negative control sequences were:

5'-UUCUCCGAACGUGUCACGUTT-3' and 5'-ACG UGACACGUUCGGAGAATT-3'. Glioma cells were transfected with 40 pmol of siRNA duplex or negative groups and exposed to $5 \mu \mathrm{M} \mathrm{As}{ }_{2} \mathrm{O}_{3}$ for 48 hours.

\section{Quantitative realtimePCR (QRT-PCR)}

Total RNA was isolated from glioma cells using Trizol reagent (Invitrogen, California, USA). It was then reversetranscribed to CDNA with random primers using a reverse transcriptase RT kit (Takara Biotechnology Co., Shiga, Japan) [22]. The mRNA levels of mitoferrin-2 expression were detected using QRT-PCR on a Light Cycler 480 (Roche Diagnostics, Basel, Switzerland) according to the manufacturer's protocol. The primer set of mitoferrin-2 was: sense, 5'-GGAGCATTCCAGGAGACA-3'; antisense, 5'-GGGTGACCGCCTATTT-3'. Each sample was checked in triplicate, and parallel reactions were performed using primers to $\beta$-actin as an internal control. The data were analyzed using the Light Cycler 480 software.

\section{Western blot analysis}

Cell extracts were prepared in ice-cold radioimmune precipitation assay lysis buffer $(150 \mathrm{mM} \mathrm{NaCl}, 1 \mathrm{mM}$ ethylene glycol tetraacetic acid (EGTA), 1\% sodium deoxycholate, $1 \%$ Triton X-100, 0.1\% SDS, 1\% Nonidet P-40, 50 mM Tris-Cl, pH 7.4) supplemented with a mixture of protease inhibitors (Roche Diagnostics, Basel, Switzerland) and centrifuged. Equivalent amounts of protein determined by Bradford assay (Bio-Rad, California, USA) in sample buffer (Invitrogen) supplemented with $10 \%$ SDS and $10 \% \beta$-mercaptoethanol were resolved on NuPAGE Tris-bis 12\% polyacrylamide gels (Invitrogen, California, USA). Proteins were transferred to polyvinylidene difluoride (PVDF) membranes (EMD Millipore, armstadt, Germany) and probed with anti-Mfrn-2 (1:100) (Santa Cruz Biotechnology, Shanghai, China) and anti- $\beta$ actin (1:1,000) (Santa Cruz Biotechnology). Membranes were developed by two-color infrared fluorescence imaging system (LI-COR Biosciences, Nebraska, USA). 


\section{ROS detection}

Glioma cells were transfected with 40 pmol of siRNA duplex or negative groups and exposed to $5 \mu \mathrm{M} \mathrm{As} \mathrm{A}_{2} \mathrm{O}_{3}$ for 48 hours. Then cells were incubated with $10 \mu \mathrm{M}$ $2^{\prime}, 7^{\prime}$-dichlorofluorescin diacetate (Sigma-Aldrich, St. Louis, MO, USA) for 30 minutes, after which they were washed. ROS generation was determined by FACS can flow cytometry (Becton-Dickinson Mountain View, CA, USA) using CellQuest software and fluorescent signals were displayed as histograms.

\section{MTT analysis}

To investigate cell viability, U87MG and T98G cells were seeded in 96-well plates at a density of $5 \times 10^{3}$ cells per well and stabilized for 24 hours. Glioma cells were transfected with $40 \mathrm{pmol}$ of siRNA duplex or negative groups and exposed to $5 \mu \mathrm{M} \mathrm{As} \mathrm{O}_{3}$ for 48 hours. The cells were incubated with new culture medium containing MTT working solution $(0.5 \mathrm{mg} / \mathrm{ml})$ for 4 hours at $37^{\circ} \mathrm{C}$. The culture supernatant was removed from the wells, and dimethyl sulfoxide (DMSO) was added. The absorbance of each well was measured at a wavelength of $490 \mathrm{~nm}$ with a reader.

\section{Apoptosis}

The apoptosis-inducing effects of $\mathrm{As}_{2} \mathrm{O}_{3}$ in U87MG and T98G cells were determined by flow cytometery using Annexin-V/FITC and propidium iodide. About $0.5 \times 10^{6}$ cells were plated in each well of a 6-well plate and transfected with $40 \mathrm{pmol}$ of siRNA duplex or negative groups and exposed to $5 \mu \mathrm{M} \mathrm{As} \mathrm{As}_{2} \mathrm{O}_{3}$ for 48 hours. Apoptosis was determined using human Annexin-V-FITC kit according to the manufacturer's instructions and analyzed by flow cytometry. Tests were repeated in triplicate.

\section{Statistical analysis}

Statistical analysis was performed by Student's $t$-test. $P$-values of $<0.05$ were considered statistically significant.
All values are expressed as mean \pm SEM from three different experiments.

\section{Results}

\section{Effects of $\mathrm{As}_{2} \mathrm{O}_{3}$ on cell viability in glioma}

The sensitivity of U87MG and T98 G cells to $\mathrm{As}_{2} \mathrm{O}_{3}$ was first investigated by MTT. Figure 1 shows that the cytotoxic effect of a 48-hour treatment with $\mathrm{As}_{2} \mathrm{O}_{3}$ was dose-dependent, and $5 \mu \mathrm{M}$ was chosen as the optimal concentration for $\mathrm{As}_{2} \mathrm{O}_{3}$ treatment in U87MG (Figure 1A) and T98G (Figure 1B).

\section{Induction of ROS and oxidative stress by $\mathrm{As}_{2} \mathrm{O}_{3}$}

To explore the effect of $\mathrm{As}_{2} \mathrm{O}_{3}$ on oxidative stress production in glioma cells, the ROS production induced by $\mathrm{As}_{2} \mathrm{O}_{3}$ in U87MG and T98G was measured. At 2 hours, 4 hours, 6 hours or 8 hours after exposure to $5 \mu \mathrm{M}$ $\mathrm{As}_{2} \mathrm{O}_{3}$, the intracellular ROS levels were increased and the peak production appeared at 6 hours and 4 hours respectively in U87MG (Figure 2A) and T98G cell lines (Figure 2B). Therefore, 6 hours and 4 hours were chosen times to monitor ROS production for the follow-up tests in U87MG and T98G, respectively.

\section{$\mathrm{As}_{2} \mathrm{O}_{3}$ enhanced the expression of mitoferrin-2 in glioma cells}

To explore the possible mechanism of $\mathrm{As}_{2} \mathrm{O}_{3}$-induced cell damage and ROS production, we measured the cellular mitoferrin-2 expression after pretreatment with $\mathrm{As}_{2} \mathrm{O}_{3}(5 \mu \mathrm{M})$ for 48 hours. Our data from QRT-PCR showed that the expression of mitoferrin-2 was increased about 4 to 5 folds in both U87MG (Figure 3A) and T98G lines (Figure 3B) after $\mathrm{As}_{2} \mathrm{O}_{3}$ pretreatment. The mitoferrin-2 expression after silencing was also measured by QRT-PCR. As shown in Figure 3, the expression rate of mitoferrin-2 mRNA decreased about $67.4 \%$ and $43.4 \%$ respectively in U87MG (Figure 4A) and T98G lines (Figure 4B) transfected with mitoferrin-2
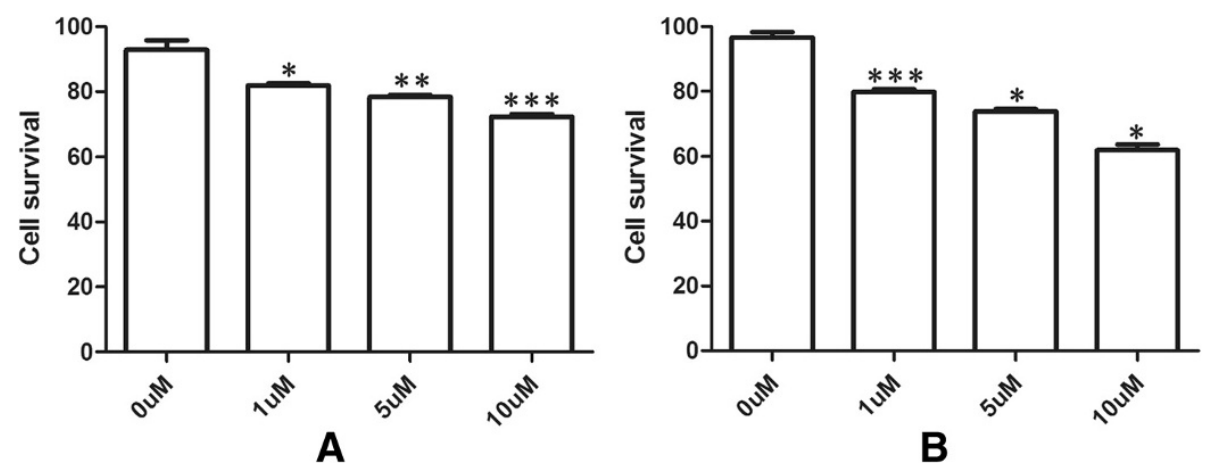

Figure 1 After exposure of human glioma cell lines U87MG (A) and T98G (B) to $\mathrm{As}_{2} \mathrm{O}_{3}$ at different doses for 48 hours, the cytotoxicity of $\mathrm{As}_{2} \mathrm{O}_{3}$ was analyzed by MTT. Student's $t$-test was used for evaluation statistical significance $\left({ }^{*} P<0.05\right)$. MTT, 3-(4,5-dimethylthiazol-2-yl)2,5-diphenyltetrazolium bromide. 

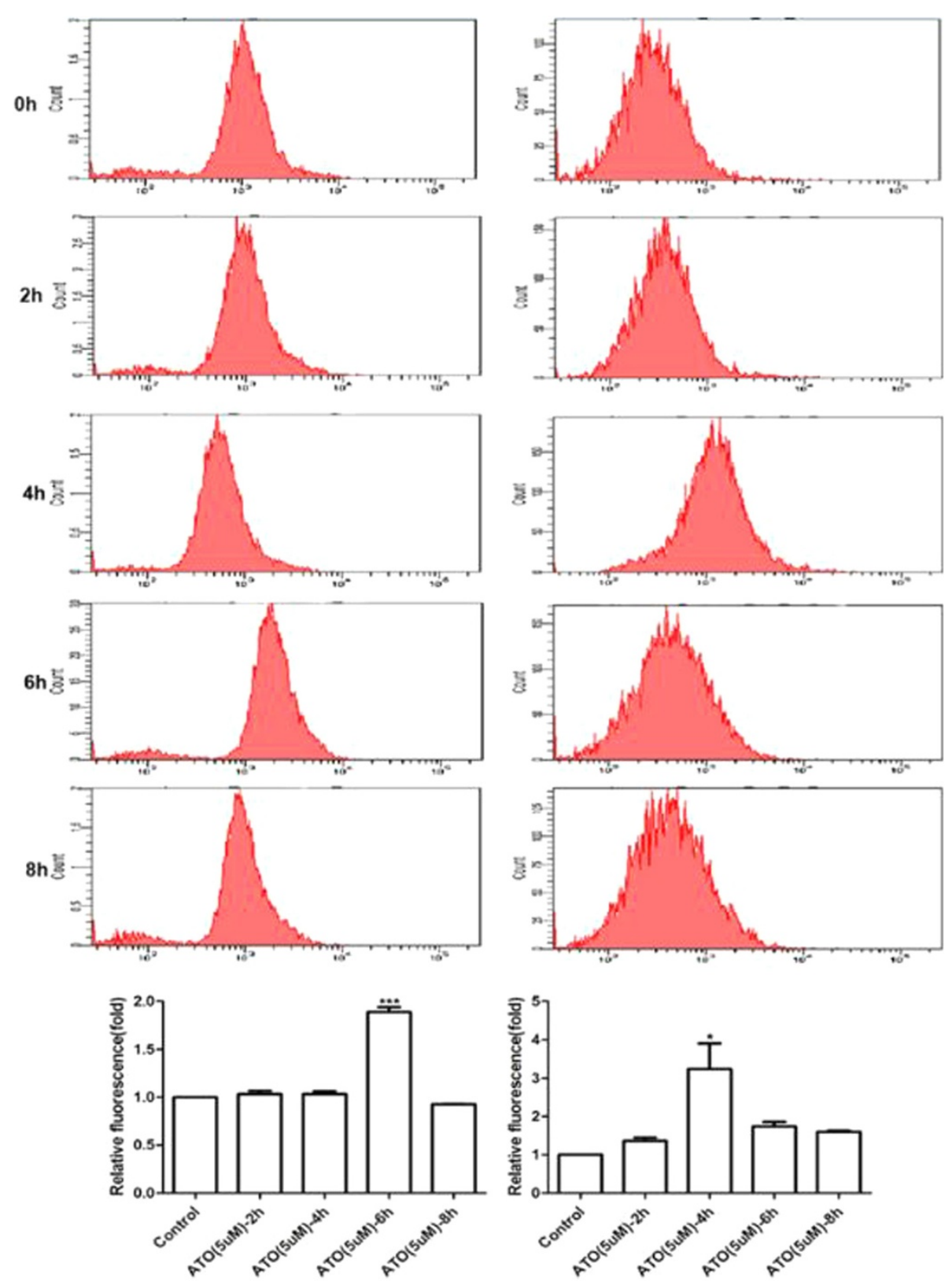

A

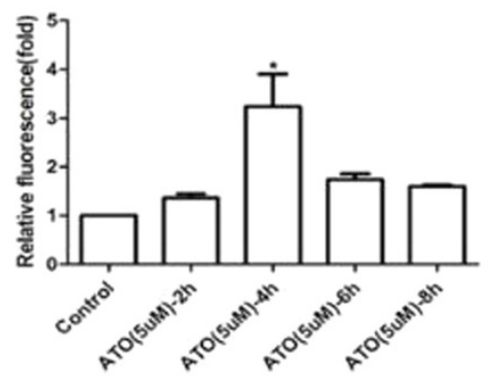

B

Figure 2 After exposure of human glioma cell lines U87MG (A) and T98G (B) to $\mathrm{As}_{2} \mathrm{O}_{3}$ at different times, the reactive oxygen species (ROS) production of $\mathrm{As}_{2} \mathrm{O}_{3}$ was analyzed by flow cytometry. Student's $t$-test was used for evaluation statistical significance $(* P<0.05)$.

siRNA as compared to negative control siRNA oligonucleotides. Mitoferrin-2 expression measured by Western blot analysis (Figure 5) produced the same results as with QRT-PCR.

\section{$\mathrm{ROS}$ production and apoptosis in $\mathrm{As}_{2} \mathrm{O}_{3}$-treated glioma} cells decreased after silencing the mitoferrin- 2 expression To confirm the role of mitoferrin-2 transporter in $\mathrm{As}_{2} \mathrm{O}_{3}$ treatment of glioma cells, we modulated mitoferrin-2 expression in U87MG and T98G by using siRNA interferencing. For those cells pretreated with $\mathrm{As}_{2} \mathrm{O}_{3}(5 \mu \mathrm{M})$, the ROS production (Figure 6), apoptosis (Figure 7) and cell death rates (Figure 8) were decreased after silencing the mitoferrin-2 transporter. siRNA-mediated inhibition of $\mathrm{As}_{2} \mathrm{O}_{3}$-induced apoptosis is greater in T98MG compared with U78MG (Figure 7). These data indicated mitoferrin-2 silencing strongly protected against ROS production induced by $\mathrm{As}_{2} \mathrm{O}_{3}$. 


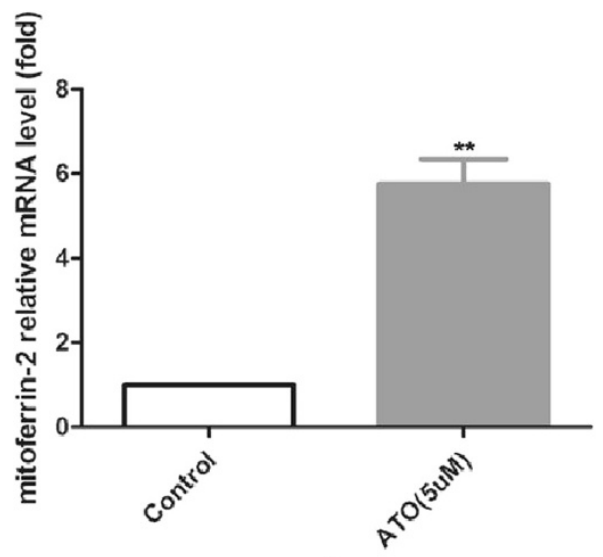

A

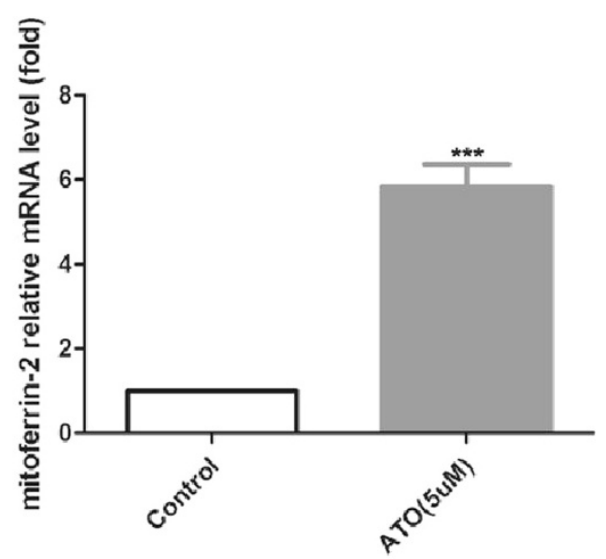

B

Figure 3 Treatment with $\mathrm{As}_{2} \mathrm{O}_{3}(5 \mu \mathrm{M}, 4$ 8hours) significantly increased intracellular mitoferrin-2 expression in glioma cells U87MG (A) and T98G lines (B). Data are presented as mean \pm SEM for the separate experiments performed in duplicate. Student's $t$-test was used to evaluate statistical significance $\left({ }^{*} P<0.05\right)$.

\section{Discussion}

$\mathrm{As}_{2} \mathrm{O}_{3}$ has achieved some efficacy in treating glioma [23-25] although the mechanism remains unclear. In our study, the results indicated that mitoferrin-2, by mediating ferrous transport across the mitochondrial inner membrane, plays a significant role in $\mathrm{As}_{2} \mathrm{O}_{3}$-induced glioma cell death. Our findings showed that the expression level of mitoferrin-2 was increased about 4 to 5 folds in both U87MG and T98G after pretreatment with $\mathrm{As}_{2} \mathrm{O}_{3}$ $(5 \mu \mathrm{M})$ after 48 hours. Next, to determine whether mitoferrin-2 mediates mitochondrial ROS production or apoptosis in $\mathrm{As}_{2} \mathrm{O}_{3}$-induced glioma cell damage, mitoferrin-2 gene expression was silenced by siRNA in glioma cells and exposed to $\mathrm{As}_{2} \mathrm{O}_{3}$ for 48 hours.
Our data showed that ROS production and apoptosis in low mitoferrin-2 expression groups were reduced compared to negative control groups in $\mathrm{As}_{2} \mathrm{O}_{3}$ pretreated glioma cells. Additionally, we firstly demonstrated that down-regulation of mitoferrin-2 expression affects $\mathrm{As}_{2} \mathrm{O}_{3}$-induced cell toxicity in human glioma cell lines U87MG and T98G. $\mathrm{As}_{2} \mathrm{O}_{3}$-induced cytotoxicity was reduced after silencing mitoferrin-2. Therefore, we assume that mitoferrin-2 transporter may partly participate in $\mathrm{As}_{2} \mathrm{O}_{3}$-induced cytotoxicity through promotion of ROS production.

Human glioma treatment is especially challenging because current treatments, such as chemical therapy, drastically affect patient quality of life. $\mathrm{As}_{2} \mathrm{O}_{3}$ has been

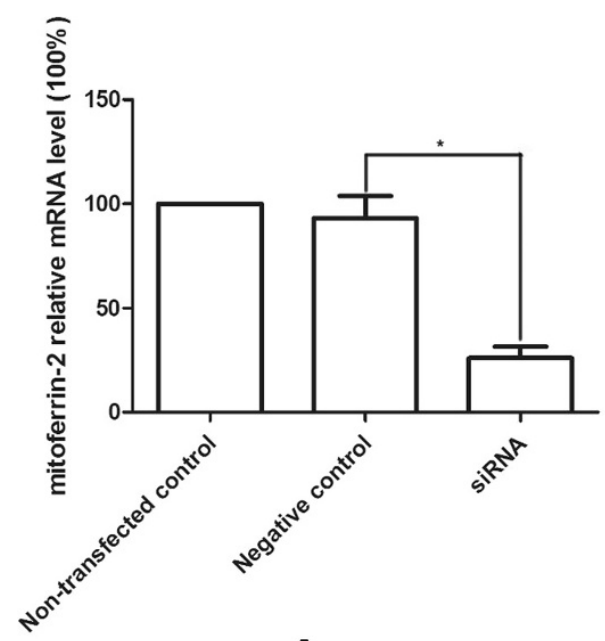

A

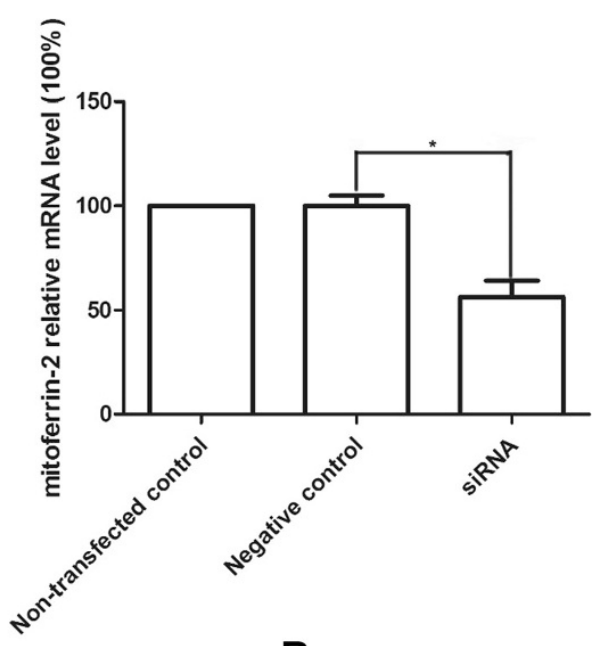

B

Figure 4 Silencing mitoferrin-2 by siRNA for $\mathbf{4 8}$ hours was shown in U87MG (A) and T98G (B) lines. Expression of mitoferrin-2 was decreased after using siRNA interferencing in both U87MG and T98G. Data are presented as mean \pm SEM for the separate experiments performed in duplicate. Student's t-test was used to evaluate statistical significance $\left({ }^{*} P<0.05\right)$. 

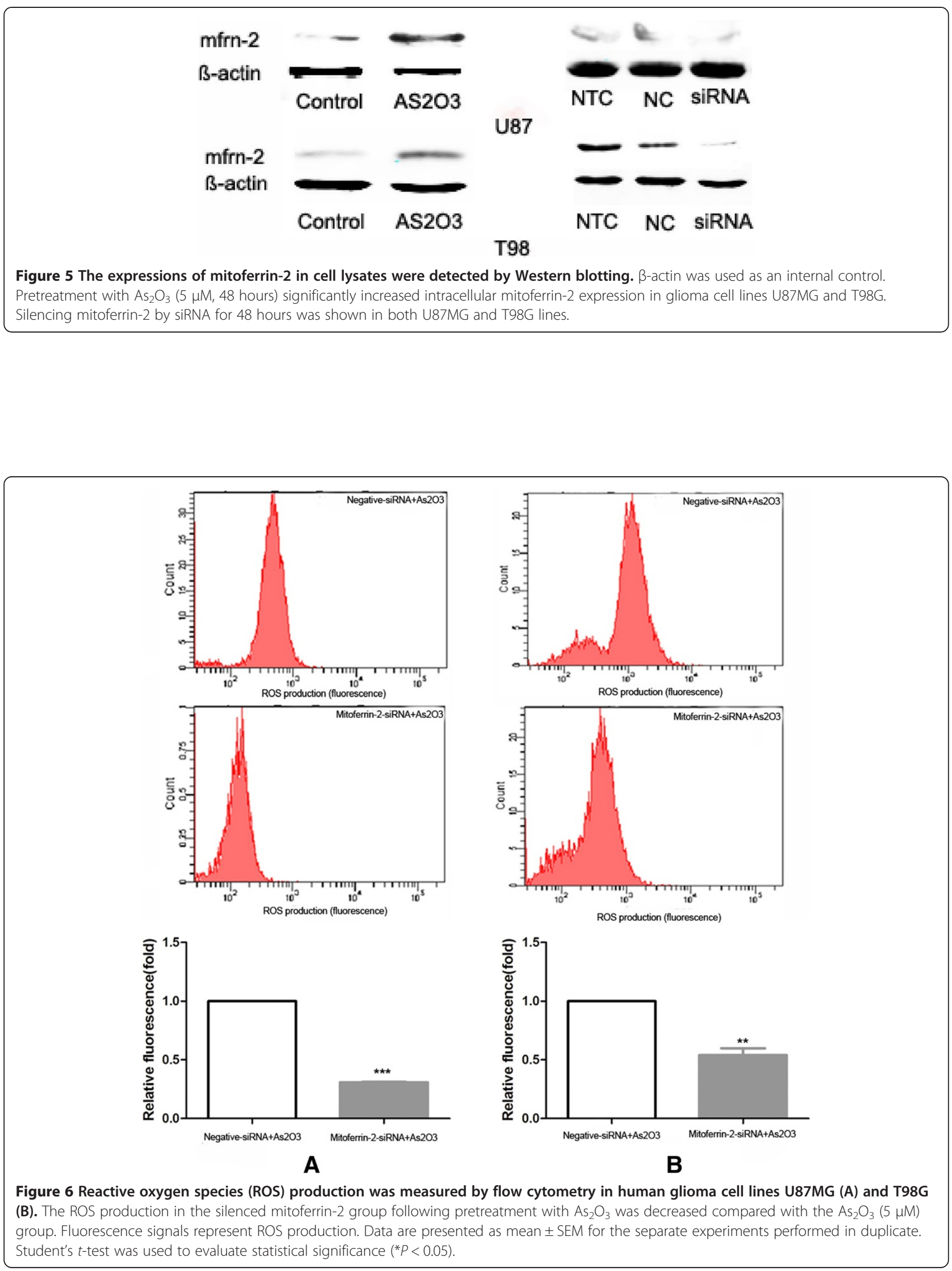


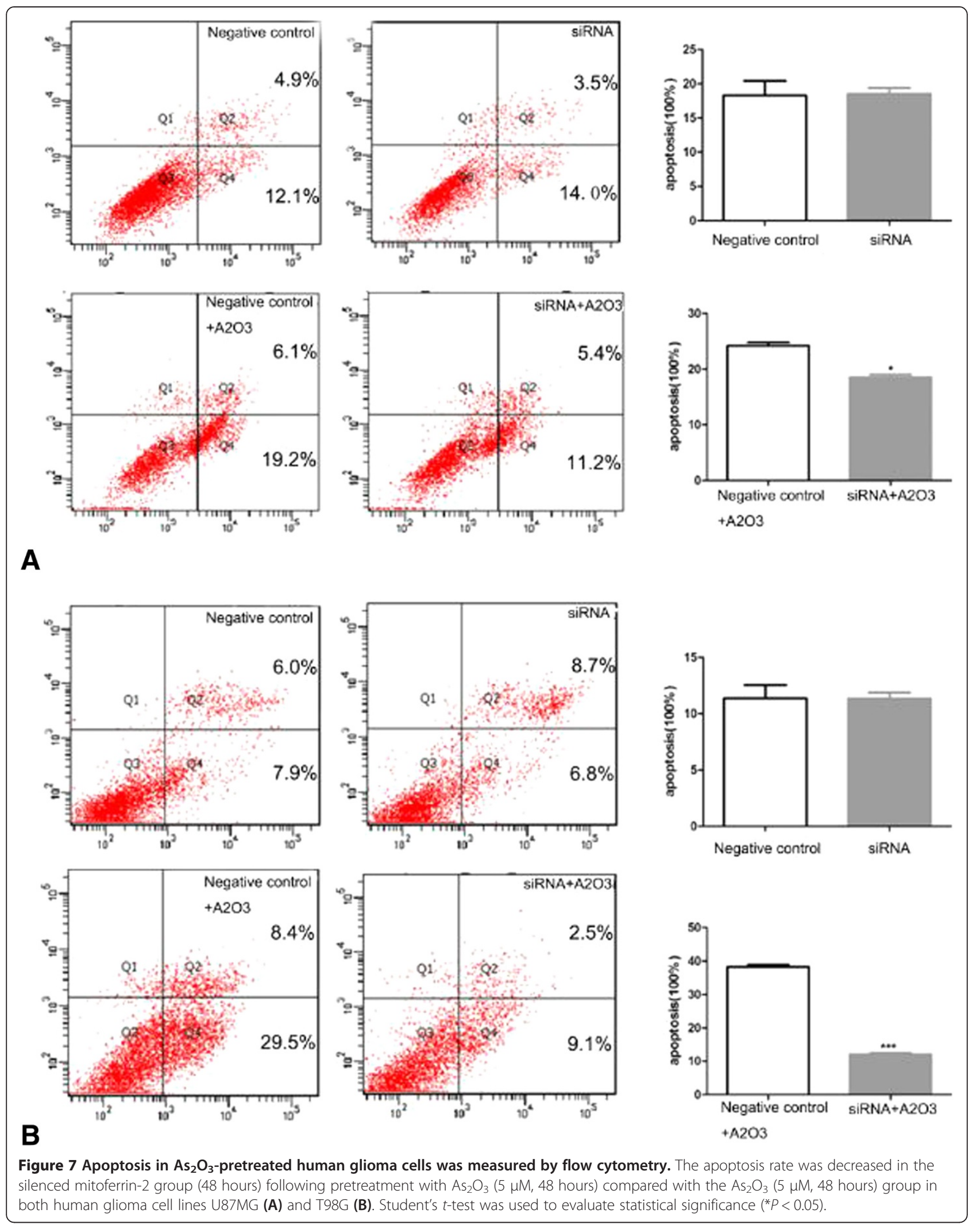



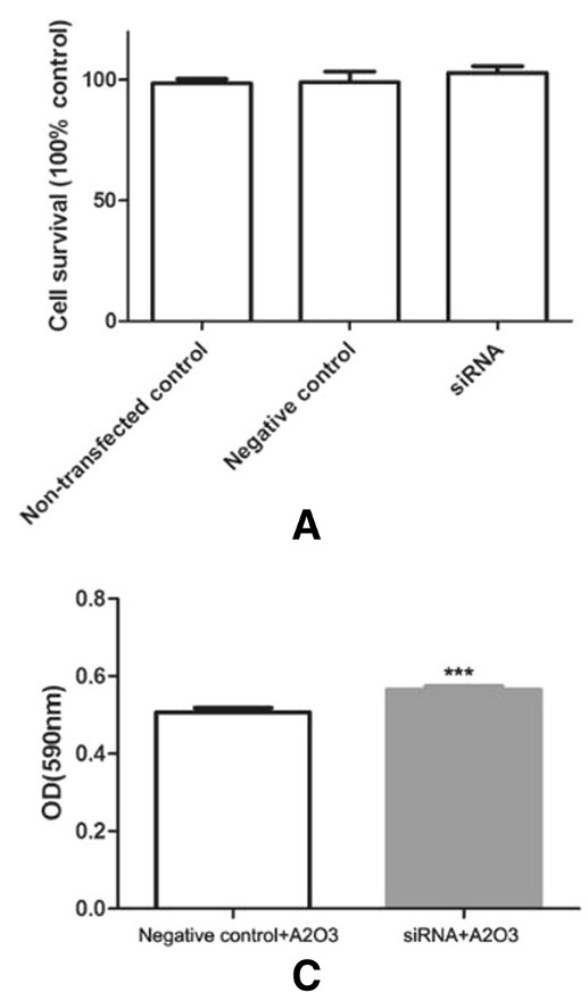

Figure 8 Proliferation in $\mathrm{As}_{2} \mathrm{O}_{3}$-pretreated human glioma cells was measured by MTT. Proliferation rates were not changed in either human glioma cell lines U87MG (A) or T98G (B) after silencing mitoferrin-2 for 48 hours. Proliferation rates were increased in the silenced mitoferrin-2 group following pretreatment with $\mathrm{As}_{2} \mathrm{O}_{3}$ for 48 hours compared with the $\mathrm{As}_{2} \mathrm{O}_{3}(5 \mu \mathrm{M})$ group in both human glioma cell lines U87MG (C) and T98G lines (D). Student's t-test was used to evaluate statistical significance $\left.{ }^{*} P<0.05\right)$. MTT, 3-(4,5-dimethylthiazol-2-yl)-2,5-diphenyltetrazolium bromide.

successfully used for gliomas in a number of clinical trials and experiments because of its significant anticancer property $[1,2]$. In previous researches, $\mathrm{As}_{2} \mathrm{O}_{3}$ (3 to 10 $\mu \mathrm{M})$ could also induce apoptosis in cultured bone marrow mesenchymal stem cells [26,27]. Additionally, treatment with high concentrations of $\mathrm{As}_{2} \mathrm{O}_{3}$ (30, 60, and 90 $\mu \mathrm{M})$ caused primary cardiomyocyte apoptosis in a doseand time-dependent manner [28]. Higher concentrations of $\mathrm{As}_{2} \mathrm{O}_{3}$ (4 to $32 \mu \mathrm{M}$ ) obviously reduced smooth muscle cell viability in a concentration-dependent manner [29]. One clinical study has indicated that the plasma levels of arsenic are 5.54 to $7.30 \mu \mathrm{M}$ in acute promyelocytic leukemia patents treated with $\mathrm{As}_{2} \mathrm{O}_{3}$ for detection of ROS activity [30]. In the present study, we found that treatment with $\mathrm{As}_{2} \mathrm{O}_{3}$ (1 to $\left.10 \mu \mathrm{M}\right)$ in glioma cell lines significantly decreases cell viability and increases cell apoptosis.

Further, $\mathrm{As}_{2} \mathrm{O}_{3}$ is a mitochondrial toxin causing $\mathrm{ROS}$ generation [31], mitochondrial transmembrane potential disappearance, and cytochrome $\mathrm{C}$ release into the cytoplasm. These phenomena could be the cause of apoptosis. Therefore, we presume that $\mathrm{As}_{2} \mathrm{O}_{3}$ induces apoptosis in tumor cells possibly by affecting mitochondrial function [22,32-38]. Our data showed that highest
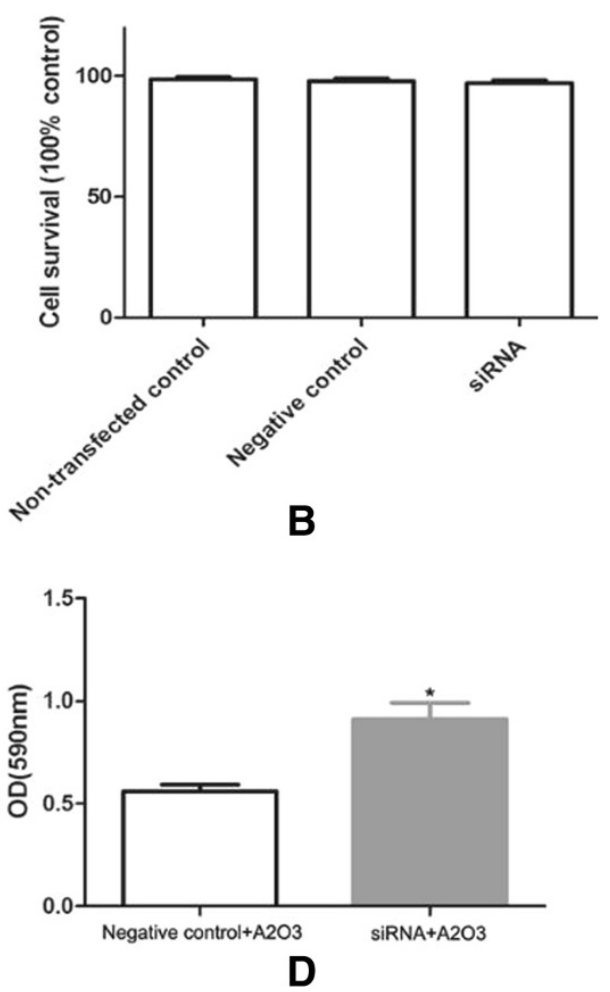
mediated and iron-dependent mitochondrial dysfunction and subsequent cancer cell killing has been reported [20]. Therefore, whether mitoferrin-2 can affect the antitumor effect of $\mathrm{As}_{2} \mathrm{O}_{3}$ should be further explored. In our experiment, mitoferrin-2 mRNA expression was upregulated in glioma cells after pretreatment with $\mathrm{As}_{2} \mathrm{O}_{3}$. Thus, mitoferrin-2 may participate in $\mathrm{As}_{2} \mathrm{O}_{3}$ treatment. Additionally, previous researches have reported that up-regulated expression of mitoferrin in yeast and mouse models of Friedreich's ataxia suggested that it is associated with the pathogenesis of diseases with mitochondrial iron accumulation [43]. Down-regulating the expression of mitoferrin-2 or blocking the iron import channel by some approaches should alleviate the symptoms of patients by preventing iron accumulation [44]. Therefore, we assume that mitoferrin-2 may regulate mitochondrial iron accumulation and participate in $\mathrm{As}_{2} \mathrm{O}_{3}$-induced $\mathrm{ROS}$ production and cell damage.

In order to further explore whether mitoferrin-2 plays a crucial role in $\mathrm{As}_{2} \mathrm{O}_{3}$-induced cytotoxicity, we measured ROS production in both down-regulated mitoferrin-2 expression groups and negative groups in glioma cells pretreated with same-concentration $\mathrm{As}_{2} \mathrm{O}_{3}$. Our data showed that ROS production in low mitoferrin-2 expression groups was reduced compared to negative groups in glioma cells pretreated with $\mathrm{As}_{2} \mathrm{O}_{3}$. This result suggests that mitoferrin-2 can regulate $\mathrm{As}_{2} \mathrm{O}_{3}$-induced ROS production in glioma cells. Additionally, mitoferrin-2 has been demonstrated to increase the iron transmitted into mitochondria and to be related to ROS production in PDT [20]. The predominant proportion of ROS production occurs inside mitochondria, leading to mitochondrial permeability transition and cell death [15]. Therefore, overall these findings suggest that mitoferrin-2 has anapoptotic-promotingrole in $\mathrm{As}_{2} \mathrm{O}_{3}$-induced glioma apoptosis and cell damage.

\section{Conclusion}

In summary, we have demonstrated for the first time that mitoferrin-2 transporter plays an important role in the antitumor effect induced by $\mathrm{As}_{2} \mathrm{O}_{3}$ in human glioma cells. These findings suggest that mitochondrial mitoferrin-2 transporter may be an important potential regulator in $\mathrm{As}_{2} \mathrm{O}_{3}$-induced glioma cell death and further understanding mechanisms in both the therapeutic activities and the toxicities of arsenic. Additionally, together with the multiple molecular targets affected by arsenic, suggests the potential for additive or even synergistic effects when arsenic is administered with other cytostatic or cytotoxic agents. Future studies are needed to investigate whether mitoferrin-2 can take part in $\mathrm{As}_{2} \mathrm{O}_{3}$ treatment in human glioma in vivo and in the clinical setting.

\section{Abbreviations}

$\mathrm{As}_{2} \mathrm{O}_{3}$ : Arsenic trioxide; ROS: Reactive oxygen species; MTT: 3-(4,5dimethylthiazol-2-yl)-2,5-diphenyltetrazolium bromide; ISC: Iron-sulfur cluster; DMSO: Dimethylsulfoxide; EDTA: Ethylenediaminetetraacetic acid QRT-PCR: Quantitative real- time -PCR; EGTA: Ethylene glycol tetraacetic acid; PVDF: Polyvinylidene difluoride; MMP: Matrix metal proteinases; PDT: Photodynamic therapy.

\section{Competing interests}

The authors declare that they have no competing interests.

\section{Authors' contributions}

XC carried out the molecular genetic studies, participated in the sequence alignment and drafted the manuscript. XC participated in the design of the study and performed the statistical analysis. $\mathrm{HZ}$ and $\mathrm{YL}$ conceived of the study, and participated in its design and coordination and helped to draft the manuscript. All authors read and approved the final manuscript.

\section{Acknowledgement}

This work was supported by grants from National Natural Science Foundation of China (30973078, 81272788 to Shiguang Zhao; 81101616 to Yunbo Zhen, and 81201974 to Lei Teng) and Foundation of the First Affiliated Hospital of Harbin Medical University (2013B05 to Xiaofeng Chen).

Received: 10 January 2014 Accepted: 27 August 2014

Published online: 26 September 2014

\section{References}

1. Song $X$, Chen Z, Wu C, Zhao S: Abrogating HSP response augments cell death induced by As2O3 in glioma cell lines. Can J Neurol Sci 2010, 37(4):504-511

2. Haga N, Fujita N, Tsuruo T: Involvement of mitochondrial aggregation in arsenic trioxide (As203)-induced apoptosis in human glioblastoma cells. Cancer Sci 2005, 96(11):825-833.

3. Yu M, Xue J, Li Y, Zhang W, Ma D, Liu L, Zhang Z: Resveratrol protects against arsenic trioxide-induced nephrotoxicity by facilitating arsenic metabolism and decreasing oxidative stress. Arch Toxicol 2013, 87(6):1025-1035

4. Murphy MP: How mitochondria produce reactive oxygen species. Biochem J 2009, 417:1-13.

5. Swanson CA: Iron intake and regulation: implications for iron deficiency and iron overload. Alcohol 2003, 30(2):99-102.

6. Kohgo Y, Ohtake T, Ikuta K, Suzuki Y, Hosoki Y, Saito H, Kato J: Iron accumulation in alcoholic liver diseases. Alcohol Clin Exp Res 2005, 29(11):189S-193S.

7. Petersen DR: Alcohol, iron-associated oxidative stress, and cancer. Alcohol 2005, 35(3):243-249.

8. Imeryuz N, Tahan V, Sonsuz A, Eren F, Uraz S, Yuksel M, Akpulat S, Ozcelik D, Haklar G, Celikel C, Avsar E, Tozun N: Iron preloading aggravates nutritional steatohepatitis in rats by increasing apoptotic cell death. J Hepatol 2007, 47(6):851-859.

9. Britton RS, Leicester $\mathrm{KL}$, Bacon BR: Iron toxicity and chelation therapy Int J Hematol 2002, 76(3):219-228.

10. Eaton JW, Qian M: Molecular bases of cellular iron toxicity. Free Radic Biol Med 2002, 32:833-840.

11. Shaw GC, Cope JJ, Li L, Corson K, Hersey C, Ackermann GE, Gwynn B, Lambert AJ, Wingert RA, Traver D, Trede NS, Barut BA, Zhou Y, Minet E, Donovan A, Brownlie A, Balzan R, Weiss MJ, Peters LL, Kaplan J, Zon LI, Paw BH: Mitoferrin is essential for erythroid iron assimilation. Nature 2006, 440:96-100

12. Uchiyama A, Kim JS, Kon K, Jaeschke H, Ikejima K, Watanabe S, Lemasters JJ: Translocation of iron from lysosomes into mitochondria is a key event during oxidative stress-induced hepatocellular injury. Hepatology 2008, 48:1644-1654

13. Vineetha VP, Prathapan A, Soumya RS, Raghu KG: Arsenic trioxide toxicity in $\mathrm{H} 9 \mathrm{c} 2$ myoblasts - damage to cell organelles and possible amelioration with Boerhavia diffusa. Cardiovasc Toxicol 2013, 13(2):123-137.

14. Richter C, Gogvadze V, Laffranchi R, Schlapbach R, Schweizer M, Suter M, Walter P, Yaffee M: Oxidants in mitochondria: from physiology to diseases. Biochim Biophys Acta 1995, 1271:67-74 
15. Trachootham D, Zhou Y, Zhang H, Demizu Y, Chen Z, Pelicano H, Chiao PJ, Achanta G, Arlinghaus RB, Liu J, Huang P: Selective killing of oncogenically transformed cells through a ROS-mediated mechanism by beta-phenylethyl isothiocyanate. Cancer Cell 2006, 10:241-252.

16. Krzywanski DM, Moellering DR, Fetterman JL, Dunham-Snary KJ, Sammy MJ, Ballinger SW: The mitochondrial paradigm for cardiovascular disease susceptibility and cellular function: a complementary concept to Mendelian genetics. Lab Invest 2011, 91(8):1122-1135.

17. Satre M, Mattei S, Aubry L, Gaudet P, Pelosi L, Brandolin G, Klein G: Mitochondrial carrier family: repertoire and peculiarities of the cellular slime mould Dictyostelium discoideum. Biochimie 2007, 89:1058-1069.

18. Froschauer EM, Schweyen RJ, Wiesenberger G: The yeast mitochondrial carrier proteins Mrs3p/Mrs4p mediate iron transport across the inner mitochondrial membrane. Biochim Biophys Acta 2009, 1788:1044-1050.

19. Paradkar PN, Zumbrennen KB, Paw BH, Ward DM, Kaplan J: Regulation of mitochondrial iron import through differential turnover of mitoferrin 1 and mitoferrin 2. Mol Cell Biol 2009, 29:1007-1016.

20. Hung HI, Schwartz JM, Maldonado EN, Lemasters JJ, Nieminen AL: Mitoferrin-2-dependent mitochondrial iron uptake sensitizes human head and neck squamous carcinoma cells to photodynamic therapy. J Biol Chem 2013, 288(1):677-686.

21. Liu Y, Zhang X, Liang Y, Yu H, Chen X, Zheng T, Zheng B, Wang L, Zhao L, Shi C, Zhao S: Targeting $X$ box-binding protein-1 (XBP1) enhances sensitivity of glioma cells to oxidative stress. Neuropathol Appl Neurobiol 2011, 37:395-405.

22. Yi J, Yang J, He R, Gao F, Sang H, Tang X, Ye RD: Emodin enhances arsenic trioxide-induced apoptosis via generation of reactive oxygen species and inhibition of survival signaling. Cancer Res 2004, 64:108-116.

23. Kim JH, Lew YS, Kolozsvary A, Ryu S, Brown SL: Arsenic trioxide enhances radiation response of $9 \mathrm{~L}$ glioma in the rat brain. Radiat Res 2003, 160(6):662-666.

24. Kanzawa T, Zhang L, Xiao L, Germano IM, Kondo Y, Kondo S: Arsenic trioxide induces autophagic cell death in malignant glioma cells by upregulation of mitochondrial cell death protein BNIP3. Oncogene 2005, 24(6):980-991.

25. Cohen KJ, Gibbs IC, Fisher PG, Hayashi RJ, Macy ME, Gore L: A phase I trial of arsenic trioxide chemoradiotherapy for infiltrating astrocytomas of childhood. Neuro Oncol 2013, 15(6):783-787.

26. Cai BZ, Meng FY, Zhu SL, Zhao J, Liu JQ, Liu CJ, Chen N, Ye ML, Li ZY, Ai J, $L u Y J$, Yang BF: Arsenic trioxide induces the apoptosis in bone marrow mesenchymal stem cells by intracellular calcium signal and caspase-3 pathways. Toxicol Lett 2010, 193:173-178.

27. Yadav S, Shi Y, Wang F, Wang H: Arsenite induces apoptosis in human mesenchymal stem cells by altering $\mathrm{Bcl}-2$ family proteins and by activating intrinsic pathway. Toxicol Appl Pharmacol 2010, 244:263-272.

28. Raghu KG, Cherian OL: Characterization of cytotoxicity induced by arsenic trioxide (a potent anti-APL drug) in rat cardiac myocytes. J Trace Elem Med Biol 2009, 23:61-68.

29. Li JX, Shen YQ, Cai BZ, Zhao J, Bai X, Lu YJ, Li XQ: Arsenic trioxide induces the apoptosis in vascular smooth muscle cells via increasing intracellular calcium and ROS formation. Mol Biol Rep 2010, 37:1569-1576.

30. Shen ZX, Chen GQ, Ni JH, Li XS, Xiong SM, Qiu QY, Zhu J, Tang W, Sun GL, Yang KQ, Chen Y, Zhou L, Fang ZW, Wang YT, Ma J, Zhang P, Zhang TD, Chen SJ, Chen Z, Wang ZY: Use of arsenic trioxide (As2O3) in the treatment of acute promyelocytic leukemia (APL): II. Clinical efficacy and pharmacokinetics in relapsed patients. Blood 1997, 89:3354-3360.

31. Yen YP, Tsai KS, Chen YW, Huang CF, Yang RS, Liu SH: Arsenic induces apoptosis in myoblasts through a reactive oxygen species-induced endoplasmic reticulum stress and mitochondrial dysfunction pathway. Arch Toxicol 2012, 86(6):923-933.

32. Kroemer $\mathrm{G}$, de The $\mathrm{H}$ : Arsenic trioxide, a novel mitochondriotoxic anticancer agent? J Natl Cancer Inst 1999, 91:743-745.

33. Zhu $X H$, Shen $Y L$, Jing $Y K$, Cai $X$, Jia PM, Huang $Y$, Tang $W$, Shi GY, Sun $Y P$, Dai J, Wang ZY, Chen SJ, Zhang TD, Waxman S, Chen Z, Chen GQ: Apoptosis and growth inhibition in malignant lymphocytes after treatment with arsenic trioxide at clinically achievable concentrations. J Natl Cancer Inst 1999, 91:772-778.

34. Mahieux R, Pise-Masison C, Gessain A, Brady JN, Olivier R, Perret E, Misteli T, Nicot C: Arsenic trioxide induces apoptosis in human T-cell leukemia virus type 1- and type 2-infected cells by a caspase-3-dependent mechanism involving Bcl-2 cleavage. Blood 2001, 98:3762-3769.
35. Kajiguchi T, Yamamoto K, Hossain K, Akhand AA, Nakashima I, Naoe T, Saito H, Emi N: Sustained activation of c-jun-terminal kinase (JNK) is closely related to arsenic trioxide-induced apoptosis in an acute myeloid leukemia (M2)-derived cell line, NKM-1. Leukemia 2003, 17:2189-2195.

36. Maeda H, Hori S, Nishitoh H, Ichijo H, Ogawa O, Kakehi Y, Kakizuka A: Tumor growth inhibition by arsenic trioxide (As2O3) in the orthotopic metastasis model of androgen-independent prostate cancer. Cancer Res 2001, 61:5432-5440.

37. Miller WH Jr, Schipper HM, Lee JS, Singer J, Waxman S: Mechanisms of action of arsenic trioxide. Cancer Res 2002, 62:3893-3903.

38. Jing Y, Dai J, Chalmers-Redman RM, Tatton WG, Waxman S: Arsenic trioxide selectively induces acute promyelocytic leukemia cell apoptosis via a hydrogen peroxide-dependent pathway. Blood 1999, 94:2102-2111.

39. Boonstra J, Post JA: Molecular events associated with reactive oxygen species and cell cycle progression in mammalian cells. Gene 2004, 4(337):1-13

40. Kanda Y, Hinata T, Kang SW, Watanabe Y: Reactive oxygen species mediate adipocyte differentiation in mesenchymal stem cells. Life Sci 2011, 89(7-8):250-258.

41. Orrenius S: Reactive oxygen species in mitochondria-mediated cell death. Drug Metab Rev 2007, 39(2-3):443-455.

42. Antonsson B, Montessuit S, Sanchez B, Martinou JC: Bax is present as a high molecular weight oligomer/complex in the mitochondrial membrane of apoptotic cells. J Bio/ Chem 2001, 276(15):11615-11623.

43. Huang ML, Becker EM, Whitnall M, Suryo Rahmanto Y, Ponka P, Richardson DR: Elucidation of the mechanism of mitochondrial iron loading in Friedreich's ataxia by analysis of a mouse mutant. Proc Natl Acad Sci US A 2009, 106:16381-16386.

44. Yaguang R, Su Y, Tan G, Ye W, Liu D, Qian X, Ding Z, Zhong Y, Zhang J, Jiang D, Zhao Y, Lu J: Reduction of mitoferrin results in abnormal development and extended lifespan in Caenorhabditis elegans. PLoS One 2012, 7(1):e29666.

\section{doi:10.1186/s40001-014-0049-5}

Cite this article as: Wang et al:: The roles of mitoferrin- 2 in the process of arsenic trioxide-induced cell damage in human gliomas. European Journal of Medical Research 2014 19:49.

\section{Submit your next manuscript to BioMed Central and take full advantage of:}

- Convenient online submission

- Thorough peer review

- No space constraints or color figure charges

- Immediate publication on acceptance

- Inclusion in PubMed, CAS, Scopus and Google Scholar

- Research which is freely available for redistribution 